\title{
Reproductive Health Knowledge Needs among Secondary School Students in Mid Nile Delta Region, Egypt
}

\author{
Nagwa N. Hegazy MD', Ibrahim A. Kabbash $\mathrm{MD}^{2}$, Asmaa O. Attalla MD \\ ${ }^{1}$ Department of Family medicine-Faculty of Medicine- Menoufia University \\ ${ }^{2}$ Department of Public Health and Community Medicine-Faculty of Medicine- Tanta University
}

Abstract:

Background: Adolescent are increasingly vulnerable to negative reproductive health outcomes, such as HIV/AIDS, STDs, violent and unwanted sex, limited access to contraceptives, and early or forced marriage. Little is known about youth educational needs relevant to reproductive health in Egypt. Objectives: The present study aims to assess the need for reproductive health information among secondary student. Methods: a cross sectional study was conducted from the beginning of October 2019 until the end of November 2019. It encompassed 942 secondary school students in Gharbia Governorate and used a predesigned questionnaire for data collection. Results: The suitable age of marriage was reported by $67.9 \%$ to be $20-30$ years. The majority of students were aware that tobacco smoking and addiction adversely affect reproductive health $74.5 \%$ and $84.1 \%$, respectively). Only $18.3 \%$ had information about risks associated with early marriage. Shyness about issues related to reproductive health was reported by $33.5 \%$, and only $15.2 \%$ reported continuous communication with parents about reproductive health. More than half of the participants (51.9\%) stated that their main source of reproductive information was the internet. Among participants, $12 \%$ reported exposure to sexual harassment, and $25.6 \%$ reported having a friend or a relative suffering from sexual harassment. The high perception of need for information as reported by students was for the following topics: masturbation and its hazards (68.3\%), issues related to male and female circumcision (64.7\%), sexually transmitted infections and AIDS (60.4\%), hazards of extramarital relations (56.9\%), and safe motherhood (54.2\%). Conclusion: secondary school students are in need of information about reproductive health. There is a need to implement appropriate programs to improve the reproductive health knowledge of secondary school students.

Keywords: Adolescent, Primary health care, Sexual health

\section{Introduction:}

Adolescence is a challenging phase of

life, within which the individual comes to

physical, sexual and social maturity.

Sexuality and reproduction are

considered among the most essential

aspects of life, thus substantial efforts

have been directed towards understanding and addressing the specific needs of this population. Nevertheless, in various parts of the world, reproductive health needs of adolescents are often poorly understood or neglected. ${ }^{(1)}$ The response of different cultures to reproductive health needs of adolescents should be based on evidence in order to

*Corresponding author: E-mail: iafkabbash@gmail.com 
help them reach a level of maturity essential to make rational decisions. To be more specific, information and services should be made available to adolescents in order to understand their sexuality, and to protect them from unwanted pregnancies, sexually transmitted diseases, and subsequent risks of infertility. In the Islamic East Mediterranean region, cultural and political sensitivities disallow devoting proper attention to that matter in public policy discussions. ${ }^{(2)}$

Over the last decade, a number of non-governmental organizations (NGOs) have been formed in Egypt, including the Egyptian Youth Association for Population and Development, in four governorates and grew out of the " "friends of the forum" of young people volunteering at the International Conference on Population and Development (ICPD) in Cairo in 1994. Despite their successes, many of these programs' effectiveness was limited, and led to subsequent intense debates within the Egyptian society. ${ }^{(3)}$ Under the influence of mass media and socioeconomic development, sexual attitudes and standards have been shifting among adolescents and young adults. ${ }^{(4-6)}$
Given the scarcity of published research on reproductive and sexual health behavior results of these programs or their effectiveness in our region, many adolescents in Egypt still lack sufficient information regarding their sexual and reproductive health. Therefore, this study was designed as a survey to assess adolescents' knowledge and to recognize their specific needs to contribute to improve their reproductive and sexual health, and to assess the effect of gender on reproductive knowledge needs.

\section{Methods:}

A Cross-sectional descriptive study was conducted from the beginning of October 2019 till the end of November, 2019. This study was carried-out in Gharbia Governorate located in the midNile Delta region, and accommodating almost 5 million people. The governorate is divided into eight administrative areas. Secondary schools are mostly located in the main capital city of each administrative area. Girls are mostly educated in separate schools from boys with only few exceptions.

The sample size was calculated to be 942 using Epi-Info software statistical package created by World Health organization and center for Disease 
Control and Prevention, Atlanta, Georgia, USA, version 2002. The criteria used for sample size calculation were $97 \%$ confidence limit and expected $50 \%$ of participants would express need for reproductive health information, and a design effect of two. Two administrative areas were selected randomly. The list of secondary schools in the selected areas were obtained from the General Directorate of Education. One school for boys and another school for girls were randomly selected from each chosen area. A proportional sample size was allocated on the four schools by weight of total students in each.

Classrooms were selected randomly form each school based on the required sample size and all students in each selected class were included in the study sample. 960 sheets were distributed, however only 942 were responded to the survey, representing a response rate of $98.1 \%$.

The study subjects were interviewed to fill a pre-designed questionnaire by authors of this paper, which included socio-demographic data, and individual-based information and opinion about need for information about reproductive health related topics. It included four parts, the first part for the sociodemographic data, the second part for knowledge related to reproductive health, the third part for the sources of information about issues related to reproductive health, and the fourth part for their needs for information about issues related to reproductive health. All questions were closed ended questions. Questions about needs of information were three options Likert scale including: do not have knowledge, partial knowledge, need more, and have enough knowledge.

Validity of the questionnaire was tested by five expert reviewers to revise. A pilot study was conducted on 25 participants (not included in the study's results) in order to evaluate the appropriateness of the study tools and to explore the potential hindrances. Reliability of the questionnaire was determined to be 0.726 using Cronbach's $\alpha$ test.

\section{Anticipated problems in the process of data collection and steps taken to prevent them:}

Society's culture and traditions formed a barrier preventing participants from freely answering reproductive health related questions. These barriers were 
overcome by explaining how important answering these questions without embarrassment was to guarantee a better future for reproductive health in Egypt. Low attendance rates in the selected male high schools also represented a major problem for collecting sufficient number of surveys. Being aware of this problem, we chose certain days when students were having their monthly assessment exams to conduct the survey.

\section{Statistical analysis of data:} Organization, tabulation, presentation and analysis of data were performed by using SPSS version 19 (Statistical Package for Social Studies version 19). Numerical data were presented as mean and standard deviation. Categorical data was presented as number and percentage. The chi square test was used to compare differences between subcategories. The level of significance was adopted at $\mathrm{p}<0.05$.

Ethical considerations: The authors received written approval from Ministry of Education (MOE) to conduct the survey in schools under its authority. Participants were informed about the purpose and procedure of the study and benefits of sharing in it. Verbal consents were obtained from the guardians' of the participants in the study. Data were collected anonymously. Confidentiality and privacy were guaranteed during the whole period of the study.

\section{Results:}

- Socio-Demographic characteristics of the respondents:

The total number of participants was 942 of which $61 \%$ were males and $39 \%$ were females. (Table 1).

\section{- Reproductive health knowledge:}

More than two thirds of the participants responded that the suitable age of marriage is between 20 and 30 years old with a statistical differences between the males and females where three quarter of males believes it is the suitable age in contrast to half of the females. When asked about if addiction represents a potential risk on reproductive health, nearly $80 \%$ of males and females had answered yes with a statistical difference $(\mathrm{p}<0.001)$. When asked about having information of nutrition and reproductive health, fewer females than males answered yes $(n=217,37 \%$ vs. $n=180$, $50 \%, \mathrm{p}<0.001)$. When asked if there is a relation between adolescent and reproductive health, one third of the participants answered correctly with a statistical difference between males and 
females $(\mathrm{n}=147,41 \%$ vs. $\mathrm{n}=188,32 \%$, $\mathrm{p}<0.001)$. On asking about the relation between masturbation and reproductive health, fewer males answered yes in contrary to females $(n=147,41 \%$ vs. $\mathrm{n}=44,7.5 \%, \mathrm{p}<0.001)$. Nearly $43 \%$ of the respondents did not have any information about the importance of the premarital counseling and almost $61 \%$ did not know the places that provide such information with a statistical difference on both (Table 2).

\section{- Sources of reproductive health information:}

Fewer males than females were shy asking about reproductive health. Nearly $44 \%$ of the respondents never communicate with parents about reproductive health issues. The main sources of data were internet, media, friends, schoolbooks and relatives. Nearly $16 \%$ of females versus $5 \%$ of males were prone to sexual harassments and knew a friend or relative exposed to sexual harassment with a statistical difference for both $(\mathrm{p}<0.001)$ (Table 3).

- Needs for information about issues related to reproductive health:

On asking the adolescent about their reproductive health needs, high perception of need for information was reported for the following topics: masturbation and its hazards (68.3\%), issues related to male and female circumcision $\quad(64.7 \%), \quad$ sexually transmitted infections and AIDS (60.4\%), hazards of extramarital relations (56.9\%) and safe motherhood (54.2\%). (Table 4).

\section{Discussion:}

This study shows alarmingly low levels of sexual and reproductive knowledge among adolescents. The majority of respondents lacked awareness about the importance of premarital counselling and its places, nutrition and reproductive health, risks associated with masturbation and the relation between adolescence and reproductive health. These findings compare with those reported elsewhere. ${ }^{(7-9)}$

The suitable age of marriage was reported by $67.9 \%$ to be $20-30$ years although the Egyptian demographic health survey (DHS) (2015), reports that overall, 3 in 4 women and a similar proportion of men think that a girl should marry by age of 20. ${ }^{(10)}$ Approximately, half of the male's participants responded that they never discuss sexual issues with their parents. This is different from young females where $43 \%$ sometimes discuss their sexual and reproductive health 
issues with their parents. This is in agreement with Mattebo et al, (2015). ${ }^{(11)}$ In the current study, Internet, media and friends were the sources from which adolescent mainly grown their knowledge of sexual issues. This finding conforms to similar results of studies conducted in Nepal and Iran on adolescent. $^{(11,12)}$ However, this result contrasts the findings of a study among adolescent males in Tehran in 2006 reporting that curriculum-based sexual education programs have been successful in providing accurate and age-appropriate information. ${ }^{(13)}$

The source of information is a crucial issue to guarantee that adolescents would get comprehensive and valid information. Incomplete and incorrect information might be more deleterious than no information. It is important that government consider adding sufficient basic information about reproductive health in the educational curriculum. The information must be included as early as possible in a gradual age adjusted manner according to needs of each age groups. The reproductive and sexual health needs of adolescents in Egypt are high, as evidenced the low level of knowledge of AIDS. Moreover, comprehensive AIDS prevalence knowledge was observed in $2.7 \%$ of females versus $4.7 \%$ in males in the Egyptian demographic health survey (DHS) issued in 2015, and these knowledge levels were less than that of 2008. ${ }^{(10)}$

There is evidence that meeting adolescents' sexual health needs with targeted education and preventive care services can aid to mitigate risky sexual behavior and its consequences on both developed and developing countries. ${ }^{(14,}$ 15) This necessitates a comprehensive sexual and reproductive health program delivered via skilled, confident health professionals or teachers who adopt a positive attitude on the matter.

Conclusion: In Egypt, counselling and access to sexual and reproductive health information and services for adolescents are still inadequate. The increased awareness of the health needs, including sexual and reproductive health needs, of adolescents has not yet resulted in sufficient provision of necessary information and services. Adolescents continue to lack the education and service needed to enable them to deal in a positive and responsible way with their sexuality. Findings of the current study can assist program planners in Egypt to 
design adequate strategies to match the needs of adolescent school students.

Ethical considerations: The research ethics committee (REC) of the Faculty of Medicine had approved this study. Administrative approval from the director of the primary health care unit was obtained. Informed consent was obtained from both participants and their guardians. The confidentiality of the data was maintained through anonymity, and the confidentiality of the results was assured.

Conflict of interest: The authors state that they have no competing interests.

Funding: There has been no significant financial support for this work.

Authors' Contributions: All authors were equally contributing to this work

Acknowledgement: Authors would like to express their great appreciation for the participants.

\section{References:}

1. World Health Organization. Pregnant adolescents: delivering on Global promises of hope. Geneva, WHO 2006

2. DeJong J, Jawad R, Mortagy I et al. The sexual and reproductive health of young people in the Arab countries and Iran. Reproductive health matters. 2005 Jan 1; 13(25):49-59.

3. Dawla S. The political and legal struggle over female genital mutilation in Egypt: five years since the ICPD. Reproductive Health Matters 1999; 7(13):128-36.

4. Gao E, Zuo X, Wang L et al. How Does Traditional Confucian Culture Influence Adolescents' Sexual Behavior in Three Asian Cities?. J Adolesc Health. 2012, 50 (3): 12-17.

5. Trent K.. Teenage childbearing: structural determinants in developing countries. J Biosoc Sci. 2008, 22: 281-292.

6. Hanassaba S, Tidwella R. Change in the premarital behavior and sexual attitudes of young Iranian women: From Tehran to Los Angeles. Counselling Psychology Quarterly. 1993, 6 (4): 281-289.

7. Rajapaksa-Hewageegana N, Piercy $\mathrm{H}$, Salway $\mathrm{S}$ et al. Sexual and reproductive knowledge, attitudes and behaviors in a school going population of Sri Lankan adolescents. Sexual \& Reproductive Healthcare. 2015; 6(1):3-8.

8. Williamson 1, Parkes A, Wight D et al. Limits to modern contraceptive 
use among young women in developing countries: a systematic review of qualitative research. Reprod Health. 2009,19;6:3. doi: $10.1186 / 1742-4755-6-3$

9. Wong LP. An exploration of knowledge, attitudes and behaviours of young multiethnic Muslimmajority society in Malaysia in relation to reproductive and premarital sexual practices. BMC public health. 2012; 12(1):865.

10. Ministry of Health and Population [Egypt], El-Zanaty and Associates [Egypt], and ICF International. 2015. Egypt Health Issues Survey 2015. Cairo, Egypt and Rockville, Maryland, USA: Ministry of Health and Population and ICF International .

11. Mattebo, M, Elfstrand, R, Karlsson, $\mathrm{U}$ et al. Knowledge and Perceptions regarding Sexual and Reproductive Health among high school students in Kathmandu, Nepal. Journal of Asian Midwives. 2015; 2(2):21-35.
12. Soltani F, Sattari M, Parsa P et al. Sources of Adolescents' Information about Sexual and Reproductive Health: Gender Similarities and Differences. Journal of Pharmaceutical Sciences and Research. 2017; 9(9):1624.

13. Mohammadi MR, Mohammad K, Farahani FK et al. Reproductive knowledge, attitudes and behavior among adolescent males in Tehran, Iran. International Family Planning Perspectives. 2006; 32(1): 35-44.

14. Allan Guttmacher Institute. Can more progress be made? Teenage sexual and reproductive behavior in developed countries (executive summary).Washington, DC: Allan Guttmacher Institute, 2001.

15. Kirby D. Emerging answers: research findings on programs to reduce teen pregnancy (summary).Washington, DC: National Campaign to Prevent Teen Pregnancy; 2001. 
Table (1): Socio-Demographic characteristics of studied secondary school students

\begin{tabular}{|c|c|c|c|c|c|c|c|c|}
\hline \multirow[t]{2}{*}{ Characteristics } & \multicolumn{2}{|c|}{ Males $(\mathbf{n}=357)$} & \multicolumn{2}{|c|}{$\begin{array}{c}\text { Females } \\
(n=585)\end{array}$} & \multicolumn{2}{|c|}{ Total $(n=942)$} & \multirow[t]{2}{*}{$\mathbf{X}^{2}$} & \multirow{2}{*}{$\mathbf{p}$} \\
\hline & $\mathrm{n}$ & $\%$ & $\mathrm{~N}$ & $\%$ & $\mathrm{n}$ & $\%$ & & \\
\hline $\begin{array}{c}\text { Residence: } \\
\text { - Urban } \\
\text { - Rural } \\
\end{array}$ & $\begin{array}{l}239 \\
118 \\
\end{array}$ & $\begin{array}{l}66.9 \\
33.1 \\
\end{array}$ & $\begin{array}{l}438 \\
147 \\
\end{array}$ & $\begin{array}{l}74.9 \\
25.1 \\
\end{array}$ & $\begin{array}{l}677 \\
265 \\
\end{array}$ & $\begin{array}{l}71.9 \\
28.1\end{array}$ & 6.887 & $0.009^{*}$ \\
\hline $\begin{array}{c}\text { Fathers' educations } \\
\text { - } \quad \text { Illiterate } \\
\text { - } \text { Primary } \\
\text { - Secondary } \\
\text { - } \text { University } \\
\end{array}$ & $\begin{array}{c}12 \\
40 \\
107 \\
188\end{array}$ & $\begin{array}{c}3.5 \\
11.5 \\
30.8 \\
54.2 \\
\end{array}$ & $\begin{array}{c}11 \\
48 \\
143 \\
383 \\
\end{array}$ & $\begin{array}{c}1.9 \\
8.2 \\
24.4 \\
65.5 \\
\end{array}$ & $\begin{array}{c}23 \\
88 \\
250 \\
571 \\
\end{array}$ & $\begin{array}{c}1.9 \\
8.2 \\
24.4 \\
61.3 \\
\end{array}$ & 12.593 & $0.001 *$ \\
\hline $\begin{array}{c}\text { Mothers' educations: } \\
\text { - Illiterate } \\
\text { - Primary } \\
\text { - Secondary } \\
\text { - University } \\
\end{array}$ & $\begin{array}{c}27 \\
35 \\
103 \\
182 \\
\end{array}$ & $\begin{array}{c}7.8 \\
10.1 \\
29.7 \\
52.4\end{array}$ & $\begin{array}{c}17 \\
51 \\
154 \\
363 \\
\end{array}$ & $\begin{array}{c}2.9 \\
8.7 \\
26.3 \\
62.1 \\
\end{array}$ & $\begin{array}{c}44 \\
86 \\
257 \\
545 \\
\end{array}$ & $\begin{array}{c}4.7 \\
9.2 \\
27.6 \\
58.5 \\
\end{array}$ & 15.731 & $0.001 *$ \\
\hline 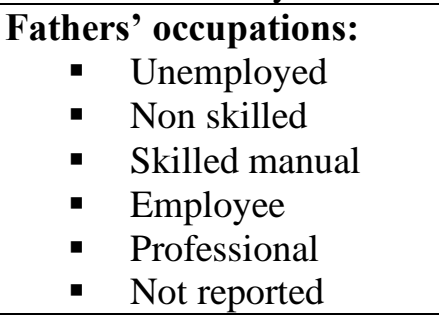 & $\begin{array}{c}6 \\
11 \\
55 \\
90 \\
132 \\
34\end{array}$ & $\begin{array}{c}1.8 \\
3.4 \\
16.8 \\
27.4 \\
40.2 \\
10.4\end{array}$ & $\begin{array}{c}11 \\
35 \\
80 \\
200 \\
255 \\
0\end{array}$ & $\begin{array}{c}1.9 \\
6.0 \\
13.8 \\
34.4 \\
43.9 \\
0.0 \\
\end{array}$ & $\begin{array}{c}17 \\
46 \\
135 \\
290 \\
387 \\
34\end{array}$ & $\begin{array}{c}1.9 \\
5.1 \\
14.9 \\
31.9 \\
42.6 \\
3.7 \\
\end{array}$ & 68.314 & $0.001 *$ \\
\hline $\begin{array}{cl}\text { Mothers' occupations: } \\
\text { - } & \text { Non skilled } \\
\text { - } & \text { Skilled } \\
\text { - } & \text { Employee } \\
\text { - } & \text { Professional } \\
\text { - } & \text { Housewife } \\
\text { - } & \text { Student } \\
\end{array}$ & $\begin{array}{c}4 \\
0 \\
41 \\
97 \\
190 \\
0 \\
\end{array}$ & $\begin{array}{c}1.2 \\
0 \\
12.3 \\
29.2 \\
57.2 \\
0.0\end{array}$ & $\begin{array}{c}2 \\
9 \\
86 \\
192 \\
293 \\
3\end{array}$ & $\begin{array}{c}0.3 \\
1.5 \\
14.7 \\
32.8 \\
50.1 \\
0.5\end{array}$ & $\begin{array}{c}6 \\
9 \\
127 \\
289 \\
483 \\
3\end{array}$ & $\begin{array}{c}0.7 \\
1.0 \\
13.8 \\
31.5 \\
52.7 \\
0.3 \\
\end{array}$ & MCET & $0.015^{*}$ \\
\hline $\begin{array}{cl}\text { Family size: } \\
\text {. } & 3 \\
= & 4 \\
= & 5 \\
= & 6 \\
\text {. } & 7+ \\
\end{array}$ & $\begin{array}{c}48 \\
74 \\
136 \\
71 \\
28 \\
\end{array}$ & $\begin{array}{c}13.4 \\
20.7 \\
38.1 \\
19.9 \\
7.8\end{array}$ & $\begin{array}{c}29 \\
95 \\
267 \\
137 \\
57 \\
\end{array}$ & $\begin{array}{c}5.0 \\
16.2 \\
45.6 \\
23.4 \\
9.7 \\
\end{array}$ & $\begin{array}{c}77 \\
169 \\
403 \\
208 \\
85 \\
\end{array}$ & $\begin{array}{c}8.2 \\
17.9 \\
42.8 \\
22.1 \\
9.0 \\
\end{array}$ & 27.12 & $0.001 *$ \\
\hline Sleeping in a separate bed & 316 & 88.5 & 400 & 68.4 & 716 & 76.0 & 49.311 & $0.001 *$ \\
\hline Having hobbies & 315 & 88.2 & 498 & 85.1 & 813 & 86.3 & 1.811 & 0.178 \\
\hline Practicing sports & 319 & 89.4 & 209 & 35.7 & 528 & 56.1 & 258.85 & $0.001 *$ \\
\hline
\end{tabular}

*statistically significant

MCET: Minimum Cross Entropy Thresholding 
Table (2): Distribution of studied secondary school students in relation to knowledge related to reproductive health

\begin{tabular}{|c|c|c|c|c|c|c|c|c|}
\hline \multirow[t]{2}{*}{ Items of knowledge } & \multicolumn{2}{|c|}{ Males (n=357) } & \multicolumn{2}{|c|}{$\begin{array}{l}\begin{array}{l}\text { Females } \\
(\mathbf{n}=585)\end{array} \\
\end{array}$} & \multicolumn{2}{|c|}{ Total $(n=942)$} & \multirow[t]{2}{*}{$\mathbf{X}^{2}$} & \multirow[t]{2}{*}{$\mathbf{p}$} \\
\hline & $\mathrm{n}$ & $\%$ & $\mathrm{n}$ & $\%$ & $\mathrm{n}$ & $\%$ & & \\
\hline $\begin{aligned} \text { Suitable age for marriage: } \\
: \quad<20 \\
: \quad 20- \\
: \quad 25- \\
: \quad 30+ \\
\end{aligned}$ & $\begin{array}{c}31 \\
203 \\
120 \\
3 \\
\end{array}$ & $\begin{array}{c}8.7 \\
56.9 \\
33.6 \\
0.8 \\
\end{array}$ & $\begin{array}{c}31 \\
437 \\
115 \\
2 \\
\end{array}$ & $\begin{array}{c}5.3 \\
74.7 \\
19.7 \\
0.3 \\
\end{array}$ & $\begin{array}{c}62 \\
640 \\
235 \\
5 \\
\end{array}$ & $\begin{array}{c}6.6 \\
67.9 \\
24.9 \\
0.5 \\
\end{array}$ & MCET & $0.001 *$ \\
\hline $\begin{array}{l}\text { Have information about risks associated with } \\
\text { early marriage } \\
\text { : No } \\
\text { - To some extend } \\
\text { - Yes }\end{array}$ & $\begin{array}{c}94 \\
191 \\
72 \\
\end{array}$ & $\begin{array}{l}26.3 \\
53.5 \\
20.2 \\
\end{array}$ & $\begin{array}{l}164 \\
321 \\
100 \\
\end{array}$ & $\begin{array}{l}28.0 \\
54.9 \\
17.1\end{array}$ & $\begin{array}{l}258 \\
512 \\
172\end{array}$ & $\begin{array}{l}27.4 \\
54.4 \\
18.3 \\
\end{array}$ & 1.459 & 0.482 \\
\hline $\begin{array}{l}\text { There is a relation between tobacco smoking } \\
\text { and reproductive health } \\
\text { - No } \\
\text { - To some extend } \\
\text { - Yes }\end{array}$ & $\begin{array}{c}40 \\
58 \\
259\end{array}$ & $\begin{array}{l}11.2 \\
16.2 \\
72.5\end{array}$ & $\begin{array}{c}40 \\
102 \\
443\end{array}$ & $\begin{array}{c}6.8 \\
17.4 \\
75.7\end{array}$ & $\begin{array}{c}80 \\
160 \\
702 \\
\end{array}$ & $\begin{array}{c}8.5 \\
17.0 \\
74.5\end{array}$ & 5.463 & 0.065 \\
\hline $\begin{array}{l}\text { Addiction represents a potential risk on } \\
\text { reproductive health } \\
\text { : No } \\
\text { - To some extend } \\
\text { - Yes }\end{array}$ & $\begin{array}{c}35 \\
35 \\
287 \\
\end{array}$ & $\begin{array}{c}9.8 \\
9.8 \\
80.4 \\
\end{array}$ & $\begin{array}{c}27 \\
53 \\
505 \\
\end{array}$ & $\begin{array}{c}4.6 \\
9.1 \\
86.3 \\
\end{array}$ & $\begin{array}{c}62 \\
88 \\
792 \\
\end{array}$ & $\begin{array}{c}6.6 \\
9.3 \\
84.1 \\
\end{array}$ & 10.18 & $0.006^{*}$ \\
\hline $\begin{array}{l}\text { Having information of nutrition and } \\
\text { reproductive health } \\
\text { - No } \\
\text { - To some extend } \\
\text { - Yes }\end{array}$ & $\begin{array}{c}44 \\
133 \\
180 \\
\end{array}$ & $\begin{array}{l}12.3 \\
37.3 \\
50.4\end{array}$ & $\begin{array}{l}115 \\
253 \\
217 \\
\end{array}$ & $\begin{array}{l}19.7 \\
43.2 \\
37.1 \\
\end{array}$ & $\begin{array}{l}159 \\
253 \\
217 \\
\end{array}$ & $\begin{array}{l}16.9 \\
43.2 \\
37.1\end{array}$ & 18.35 & $0.001 *$ \\
\hline $\begin{array}{l}\text { There is a relation between adolescent and } \\
\text { reproductive health } \\
\text { - No } \\
\text { - To some extend } \\
\text { - Yes }\end{array}$ & $\begin{array}{l}104 \\
106 \\
147\end{array}$ & $\begin{array}{l}29.1 \\
29.7 \\
41.2\end{array}$ & $\begin{array}{l}273 \\
124 \\
188\end{array}$ & $\begin{array}{l}46.7 \\
21.2 \\
32.1\end{array}$ & $\begin{array}{l}377 \\
230 \\
335 \\
\end{array}$ & $\begin{array}{l}40.0 \\
24.4 \\
35.6\end{array}$ & 28.68 & $0.001 *$ \\
\hline $\begin{array}{l}\text { Relation between masturbation and } \\
\text { reproductive health } \\
\text { - No } \\
\text { - To some extend } \\
\text { - Yes }\end{array}$ & $\begin{array}{c}115 \\
95 \\
147\end{array}$ & $\begin{array}{l}32.2 \\
26.6 \\
41.2 \\
\end{array}$ & $\begin{array}{c}485 \\
56 \\
44 \\
\end{array}$ & $\begin{array}{c}82.9 \\
9.6 \\
7.5 \\
\end{array}$ & $\begin{array}{l}600 \\
151 \\
191 \\
\end{array}$ & $\begin{array}{l}63.7 \\
16.0 \\
20.3 \\
\end{array}$ & 253.4 & $0.001 *$ \\
\hline $\begin{array}{l}\text { Have information on importance of premarital } \\
\text { counseling and testing } \\
\text { - No } \\
\text { - To some extend } \\
\text { - Yes }\end{array}$ & $\begin{array}{l}128 \\
126 \\
103\end{array}$ & $\begin{array}{l}35.9 \\
35.3 \\
28.9\end{array}$ & $\begin{array}{l}280 \\
190 \\
115\end{array}$ & $\begin{array}{l}47.9 \\
32.5 \\
19.7\end{array}$ & $\begin{array}{l}408 \\
316 \\
218\end{array}$ & $\begin{array}{l}43.3 \\
33.5 \\
23.1\end{array}$ & 16.00 & $0.001 *$ \\
\hline $\begin{array}{l}\text { Have information on places providing } \\
\text { premarital counseling and testing } \\
\text { - No } \\
\text { - To some extend } \\
\text { - Yes }\end{array}$ & $\begin{array}{c}170 \\
113 \\
74\end{array}$ & $\begin{array}{l}47.6 \\
31.7 \\
20.7\end{array}$ & $\begin{array}{c}411 \\
114 \\
60\end{array}$ & $\begin{array}{l}70.3 \\
19.5 \\
10.3\end{array}$ & $\begin{array}{l}581 \\
227 \\
134\end{array}$ & $\begin{array}{l}61.7 \\
24.1 \\
14.2\end{array}$ & 49.13 & $0.001 *$ \\
\hline
\end{tabular}

*Statistically Significant

MCET: Minimum Cross Entropy Thresholding 
Table (3): Distribution of studied secondary school students in relation to sources of information about issues related to reproductive health

\begin{tabular}{|c|c|c|c|c|c|c|c|c|}
\hline \multirow[t]{2}{*}{ Variables } & \multicolumn{2}{|c|}{$\begin{array}{c}\text { Males } \\
(n=357)\end{array}$} & \multicolumn{2}{|c|}{$\begin{array}{c}\text { Females } \\
(n=585)\end{array}$} & \multicolumn{2}{|c|}{$\begin{array}{c}\text { Total } \\
(\mathrm{n}=942)\end{array}$} & \multirow[t]{2}{*}{$\mathbf{X}^{2}$} & \multirow[t]{2}{*}{$\mathbf{P}$} \\
\hline & $\mathrm{N}$ & $\%$ & $\mathrm{n}$ & $\%$ & $\mathrm{n}$ & $\%$ & & \\
\hline Shy asking about reproductive health & 92 & 25.8 & 224 & 38.3 & 316 & 33.5 & 15.59 & $0.001 *$ \\
\hline $\begin{array}{l}\text { Communicate with parents about } \\
\text { reproductive health issues } \\
\text { - Never } \\
\text { - Sometimes } \\
\text { - Always }\end{array}$ & $\begin{array}{c}178 \\
135 \\
44\end{array}$ & $\begin{array}{l}49.9 \\
37.8 \\
12.3\end{array}$ & $\begin{array}{c}234 \\
252 \\
99\end{array}$ & $\begin{array}{l}40.0 \\
43.1 \\
16.9\end{array}$ & $\begin{array}{l}412 \\
387 \\
143\end{array}$ & $\begin{array}{l}43.7 \\
41.1 \\
15.2\end{array}$ & 9.510 & $0.009 *$ \\
\hline \multicolumn{9}{|l|}{$\begin{array}{l}\text { Main sources about reproductive } \\
\text { health:** }\end{array}$} \\
\hline - School books & 91 & 25.5 & 170 & 29.1 & 261 & 27.7 & 1.410 & 0.235 \\
\hline - Relatives & 51 & 14.3 & 207 & 35.4 & 258 & 27.4 & 49.627 & $0.001 *$ \\
\hline - Friends & 173 & 48.5 & 93 & 15.9 & 266 & 28.2 & 116.00 & $0.001 *$ \\
\hline - $\quad$ Media & 100 & 28.0 & 238 & 40.7 & 338 & 35.9 & 15.476 & $0.001 *$ \\
\hline - Internet & 260 & 72.8 & 229 & 39.1 & 489 & 51.9 & 100.76 & $0.001 *$ \\
\hline Ever exposed to sexual harassment & 18 & 5.0 & 95 & 16.2 & 113 & 12.0 & 26.331 & $0.001 *$ \\
\hline $\begin{array}{l}\text { Know a friend or relative exposed to } \\
\text { sexual harassment }\end{array}$ & 67 & 18.8 & 174 & 29.4 & 241 & 25.6 & 14.029 & $0.001 *$ \\
\hline
\end{tabular}




\section{Table (4): Distribution of studied secondary school students in relation to their needs} for information about issues related to reproductive health

\begin{tabular}{|c|c|c|c|c|c|c|c|c|}
\hline \multirow[t]{2}{*}{ Variables } & \multicolumn{2}{|c|}{$\begin{array}{c}\text { Males } \\
(n=357)\end{array}$} & \multicolumn{2}{|c|}{$\begin{array}{c}\text { Females } \\
(n=585)\end{array}$} & \multicolumn{2}{|c|}{ Total $(n=942)$} & \multirow[t]{2}{*}{$\mathbf{X}^{2}$} & \multirow[t]{2}{*}{$\mathbf{p}$} \\
\hline & $\mathrm{n}$ & $\%$ & $\mathrm{n}$ & $\%$ & $\mathrm{n}$ & $\%$ & & \\
\hline $\begin{array}{l}\text { Structure and functions of male } \\
\text { genital organs } \\
\text { - Don't have knowledge } \\
\text { - Partial knowledge and need } \\
\text { - Hore } \\
\text { - Have enough } \\
\end{array}$ & $\begin{array}{r}84 \\
141 \\
132 \\
\end{array}$ & $\begin{array}{l}23.5 \\
39.5 \\
37.0 \\
\end{array}$ & $\begin{array}{c}291 \\
224 \\
70 \\
\end{array}$ & $\begin{array}{l}49.7 \\
38.3 \\
12.0\end{array}$ & $\begin{array}{l}375 \\
265 \\
202 \\
\end{array}$ & $\begin{array}{l}39.9 \\
38.7 \\
21.4 \\
\end{array}$ & 103.18 & $0.001 *$ \\
\hline $\begin{array}{l}\text { Structure and functions of female } \\
\text { genital organs } \\
\text { - Don't have knowledge } \\
\text { - Partial knowledge need more } \\
\text { - Have enough } \\
\end{array}$ & $\begin{array}{c}147 \\
125 \\
85 \\
\end{array}$ & $\begin{array}{l}41.2 \\
35.0 \\
23.8 \\
\end{array}$ & $\begin{array}{l}149 \\
271 \\
165 \\
\end{array}$ & $\begin{array}{l}25.5 \\
46.3 \\
28.2 \\
\end{array}$ & $\begin{array}{l}296 \\
396 \\
250 \\
\end{array}$ & $\begin{array}{l}31.5 \\
42.0 \\
26.5 \\
\end{array}$ & 25.767 & $0.001 *$ \\
\hline $\begin{array}{l}\text { Psychological and physical changes } \\
\text { with puberty } \\
\text { - Don't have knowledge } \\
\text { - Partial knowledge need more } \\
\text { - Have enough } \\
\end{array}$ & $\begin{array}{c}97 \\
116 \\
144 \\
\end{array}$ & $\begin{array}{l}27.2 \\
32.5 \\
40.3 \\
\end{array}$ & $\begin{array}{c}96 \\
274 \\
215 \\
\end{array}$ & $\begin{array}{l}16.4 \\
46.8 \\
36.8 \\
\end{array}$ & $\begin{array}{l}193 \\
390 \\
359 \\
\end{array}$ & $\begin{array}{l}20.5 \\
41.4 \\
38.1 \\
\end{array}$ & 24.296 & $0.001 *$ \\
\hline $\begin{array}{l}\text { Personal hygiene to maintain } \\
\text { reproductive health } \\
\text { - Don't have knowledge } \\
\text { - Partial knowledge need more } \\
\text { - Have enough } \\
\end{array}$ & $\begin{array}{l}131 \\
108 \\
118 \\
\end{array}$ & $\begin{array}{l}36.6 \\
30.3 \\
33.1 \\
\end{array}$ & $\begin{array}{l}230 \\
223 \\
132 \\
\end{array}$ & $\begin{array}{l}39.3 \\
38.1 \\
22.6 \\
\end{array}$ & $\begin{array}{l}361 \\
331 \\
250 \\
\end{array}$ & $\begin{array}{l}38.4 \\
35.1 \\
26.5 \\
\end{array}$ & 13.494 & $0.001 *$ \\
\hline $\begin{array}{l}\text { Masturbation and its hazards } \\
\text { - Don't have knowledge } \\
\text { - Partial knowledge need more } \\
\text { - Have enough }\end{array}$ & $\begin{array}{c}156 \\
93 \\
108 \\
\end{array}$ & $\begin{array}{l}43.7 \\
26.1 \\
30.3 \\
\end{array}$ & $\begin{array}{c}488 \\
65 \\
32 \\
\end{array}$ & $\begin{array}{c}83.4 \\
11.1 \\
5.5\end{array}$ & $\begin{array}{l}644 \\
158 \\
140 \\
\end{array}$ & $\begin{array}{l}68.4 \\
16.8 \\
14.9 \\
\end{array}$ & 172.28 & $0.001 *$ \\
\hline $\begin{array}{l}\text { Issues related to male and female } \\
\text { circumcision } \\
\text { - Don't have knowledge } \\
\text { - Partial knowledge need more } \\
\text { - Have enough }\end{array}$ & $\begin{array}{c}225 \\
69 \\
63 \\
\end{array}$ & $\begin{array}{l}63.0 \\
19.3 \\
17.7 \\
\end{array}$ & $\begin{array}{c}384 \\
145 \\
56 \\
\end{array}$ & $\begin{array}{c}65.6 \\
24.8 \\
9.6 \\
\end{array}$ & $\begin{array}{l}609 \\
214 \\
119 \\
\end{array}$ & $\begin{array}{l}64.7 \\
22.7 \\
12.6 \\
\end{array}$ & 14.584 & $0.001 *$ \\
\hline $\begin{array}{l}\text { Hazards of extramarital sexual } \\
\text { relations } \\
\text { - Don't have knowledge } \\
\text { - Partial knowledge need more } \\
\text { - Have enough }\end{array}$ & $\begin{array}{c}174 \\
92 \\
91 \\
\end{array}$ & $\begin{array}{l}48.7 \\
25.8 \\
25.5 \\
\end{array}$ & $\begin{array}{c}362 \\
147 \\
76 \\
\end{array}$ & $\begin{array}{l}61.9 \\
25.1 \\
13.0 \\
\end{array}$ & $\begin{array}{l}536 \\
239 \\
167 \\
\end{array}$ & $\begin{array}{l}56.9 \\
25.4 \\
17.7 \\
\end{array}$ & 26.301 & $0.001 *$ \\
\hline $\begin{array}{l}\text { Sexually transmitted infections and } \\
\text { AIDS } \\
\text { - Don't have knowledge } \\
\text { - Partial knowledge need more } \\
\text { - Have enough }\end{array}$ & $\begin{array}{c}179 \\
95 \\
83 \\
\end{array}$ & $\begin{array}{l}50.2 \\
26.6 \\
23.2 \\
\end{array}$ & $\begin{array}{c}390 \\
143 \\
52 \\
\end{array}$ & $\begin{array}{c}66.7 \\
24.4 \\
8.9 \\
\end{array}$ & $\begin{array}{l}569 \\
238 \\
135 \\
\end{array}$ & $\begin{array}{l}60.4 \\
25.3 \\
14.3 \\
\end{array}$ & 42.339 & $0.001 *$ \\
\hline $\begin{array}{l}\text { Safe motherhood } \\
\text { Don't have knowledge } \\
\text { Partial knowledge need more } \\
\text { Have enough }\end{array}$ & $\begin{array}{c}206 \\
87 \\
64\end{array}$ & $\begin{array}{l}57.7 \\
24.4 \\
17.9\end{array}$ & $\begin{array}{c}304 \\
228 \\
53\end{array}$ & $\begin{array}{c}52.0 \\
39.0 \\
9.0\end{array}$ & $\begin{array}{l}510 \\
315 \\
117\end{array}$ & $\begin{array}{l}54.2 \\
33.4 \\
12.4\end{array}$ & 29.525 & $0.001 *$ \\
\hline
\end{tabular}

*Significant 


\section{الملخص العربي}

\section{احتياجات معرفة الصحة الإنجابية لاى طلاب المدارس الثانوية في محافظة الغربية ، مصر}

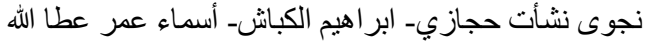
الخلفية: المر اهقون عرضة بشكل متز ايد لنتائج الصحة الإنجابية السلبية. مثل فيروس نقص المناعة البشرية / الإيدز والأمر اض المنقولة جنسيا ، و الجنس العنيف و غير المرغوب فيه ، ومحدودية الوصول إلى وسائل منع الحمل ، و الزواج المبكر أو القسري. لا يُعرف الكثير عن الاحتباجات التعليمية للثباب حول الصحة الإنجابية في مصر .الأهداف: تقييم الاحتياجات من معلومات الصحة الإنجابية بين الطلاب.منهجيه البحث: در اسة مقطعية شملت 942 من طلاب المدارس الثنانوية في محافظة الغربية باستخدام استبيان محدد سلفا. النتائج: تم الإبلاغ عن سن الزواج المناسب بنسبة 67.9 \% ليكون 20-30 سنة. أدرك غالبية الطلاب أن تدخين التبغ و إدمانه يؤثران سلبًا على الصحة الإنجابية 74.5٪ و 84.1\% على التو الي. 18.3٪ فقط لديهم معلومات حول المخاطر المرتبطة بالزواج المبكر. كانت نسبة الإرشاد قبل الزواج والأماكن التي تقدم هذه الخدمة معروفة بنسبة 23.1\%. و 14.2٪ على التوالي ، أبلغ 33.5٪ عن الخجل فيما يتعلق بالقضايا المتعلقة بالصحة الإنجابية و

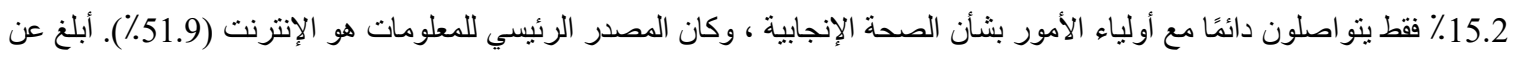
تعرضهم للتحرش الجنسي ، و أفاد 6.6 25 بأن لديهم صديق أو قريب يعاني من التحرش الجنسي ، وكان التصور المرتفع للحاجة إلى المعلومات

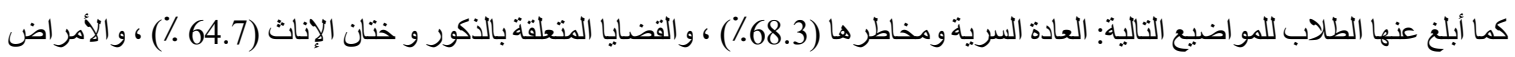
التي تنتقل عن طريق الاتصال الجنسي والإيدز (60.4 ٪) ، ومخاطر العلاقات خارج إطار الزواج (56.9 \%) والأمومة المأمونة (54.2 \%).الاستنتاجات: يحتاج طلاب المدارس الثانوية إلى معلومات حول الصحة الإنجابية. هنالك حاجة إلى تنفيذ البر امج المناسبة

$$
\text { لتحسين الصحة الإنجابية لطلاب المدارس. }
$$

